\title{
Nutritional and Technological Characteristics of New Cowpea (Vigna unguiculata) Lines and Varieties Grown in Eastern Kenya
}

\author{
Peter K. Biama1 ${ }^{*}$, Abdul K. Faraj1', Christopher M. Mutungi'2, Isaac N. Osuga ${ }^{3}$, Rose W. Kuruma ${ }^{4}$ \\ ${ }^{1}$ Dairy and Food Science and Technology Department, Egerton University, Nakuru, Kenya \\ ${ }^{2}$ International Institute of Tropical Agriculture (IITA), Dar es Salaam, Tanzania \\ ${ }^{3}$ Department Animal Science, School of Natural Resource and Animal Sciences, Jomo Kenyatta University of Agriculture and \\ Technology, Nairobi, Kenya \\ ${ }^{4}$ Kenya Agricultural and Livestock Research Organization (KALRO) Katumani, Kenya \\ Email: *peter.biama@gmail.com
}

How to cite this paper: Biama, P.K., Faraj, A.K., Mutungi, C.M., Osuga, I.N. and Kuruma, R.W. (2020) Nutritional and Technological Characteristics of New Cowpea (Vigna unguiculata) Lines and Varieties Grown in Eastern Kenya. Food and Nutrition Sciences, 11, 416-430.

https://doi.org/10.4236/fns.2020.115030

Received: March 15, 2020

Accepted: May 25, 2020

Published: May 28, 2020

Copyright (c) 2020 by author(s) and Scientific Research Publishing Inc. This work is licensed under the Creative Commons Attribution International License (CC BY 4.0).

http://creativecommons.org/licenses/by/4.0/ Open Access

\begin{abstract}
Protein sources in the diet of people living in semi-arid land of Kenya are lacking and if available it is costly to them. In terms of safe food and a healthy food supply, cowpeas (Vigna unguiculata.) are a significant source of protein, carbohydrates, and minerals especially for poor populations in the Kenya, it is said to be poor man's meat. The aim of this study was to determine nutritional composition of newly bred ten cowpea lines and five varieties commonly grown in Eastern Kenya of Kitui, Machakos and Makueni counties to understand their potential utilization in curbing rising food and nutrition insecurity in arid and semi-arid lands ASALs and in any other food applications in Kenya. The experiment was arranged in Completely Randomized Design (CRD) whereby proximate composition and minerals were determined using standard AOAC and AACC methods and technological characteristics checked using modified methods used by other researchers. Collected data were subjected to Analysis of Variance (ANOVA) using SAS (2006) version 9.1, mean separation was done using Tukey's Honestly Significant Difference (HSD) method at $5 \%$ level of significance. Cowpeas composition ranged from $12.28 \%-13.35 \%$ for moisture content, $49.37 \%-55.74 \%$ for total carbohydrates, $2.99 \%-3.34 \%$ for crude ash, $0.13 \%-0.81 \%$ for crude lipids, $23.37 \%$ $29.70 \%$ for crude protein and $1.40 \%-4.34 \%$ for crude fibers. Cowpea samples recorded highest percentage of essential amino acids $(60.71 \%)$ and non-essential amino acids (39.29\%). Minerals ranged from 1.97 - $2.69 \mathrm{mg} / 100 \mathrm{~g}$ for calcium, 3.23 - $3.90 \mathrm{mg} / 100 \mathrm{~g}$ for magnesium, $205.53-223.30 \mathrm{mg} / 100 \mathrm{~g}$ for sodium, $0.80-1.23 \mathrm{mg} / 100 \mathrm{~g}$ for zinc, $1071.15-1152.62 \mathrm{mg} / 100 \mathrm{~g}$ for potassium and $0.62-1.06 \mathrm{mg} / 100 \mathrm{~g}$ for phosphorus. For technological properties, lines ab-
\end{abstract}


sorbed water equivalent to their weights and they were comparable to varieties grown in the region. From the results it showed that cowpea line IT97K-1042-3, TEXAN PINKIYE, TX123, IT85F-867-5, IT82D-889-1 and IT82D-889 have desirable attributes such as high crude protein contents, good water absorption capacities and volumetric expansion. They compared well with existing K80 variety. These cowpea lines could possibly be bred and combined into a single cowpea line and further improved by breeders to have other good properties such as higher levels of water absorption during soaking hence reduced cooking times. Therefore, this work has shown that cowpea lines developed can be used as food security crop, industrial food applications and enriching foods of low protein like in complementary foods for healthy food supply in Eastern Kenya.

\section{Keywords}

Cowpea, Lines, Varieties, Eastern Kenya, Nutritional, Technological Characteristics

\section{Introduction}

Food and nutrition security is still a development challenge for Kenya whereby $25 \%$ of the country's population suffers chronic food insecurity and poor nutrition especially in Arid and Semi-arid lands (ASALs). Over US $\$ 1.3$ billion is used in the importation of food annually [1] [2]. A changing climate, a growing world population, and a reduction in arable land devoted to food production are all problems facing Kenya food security. The development of crops that can yield under uncertain and extreme climatic and soil growing conditions can play a key role in mitigating these problems [3]. Frequent food shortages have been reported especially in ASALs areas. Furthermore, about 5\% of the country's Kenyan population depends on food aid [4]. Low levels of human development and high levels of poverty, increasing vulnerability in Kenya's ASALs, climate stresses, especially drought, have caused greater consequences in these areas, such as acute food shortages leading to severe acute malnutrition widely prevalent problem in developing countries and a major cause of morbidity and mortality [5].

Kenya's drought conditions are expected to persist due to climatic changes leaving 3.4 million people severely food insecure and an estimated 500,000 people without access to food and water [6]. An estimated 482,882 children require treatment for acute malnutrition, including 104,614 who are suffering from severe acute malnutrition (SAM), 83,691 are from 23 arid and semi-arid counties of Kenya [6]. Cowpea (Vigna unguiculata L.) is a nutritious crop which does well in ASALs because of its heat and drought tolerance, making it an environmental and climate-change friendly crop. It is an important source of quality dietary protein to millions of people living in ASALs and is the most widely 
produced pulse grain after common dry beans (Phaseolus vulgaris), and chickpea (Cicer arietinum) [7]. Therefore, this crop can be a solution to many food insecurity challenges in this part of Kenya.

Cowpea can be utilized by both human and livestock. It has agronomical and social benefits and takes a relatively short time to mature [8] [9] [10]. Efforts aimed at breeding and improving cowpea varieties for specific characteristics such as high yield, early maturity, desired seed quality, resistance to insects and diseases have been reported [11]. Little has been done on checking on nutritive and technological properties in these new varieties produced and consumed in Kenya. Therefore, the selection of new cowpeas lines of high proteins and minerals contents is important for human health mainly for the low-income population in the ASALs regions. From the literature, elemental composition of various cowpea accessions in Kenya is not known, though the crop can serve as a good and cheap source of plant protein for school children, pregnant women, and all adults in semi-arid lands.

This study aims at determining proximate, minerals and technological characteristics, leading to consumer acceptability of new cowpea lines as compared to the existing varieties grown in Machakos, Kitui and Makueni counties. This will offer a solution to food insecurity, malnutrition and recommend best cowpeas lines to be used by farmers and consumers in the region and later in most parts of ASALs Kenya.

\section{Materials and Methods}

The study was conducted at Guildford Dairy Institute, Department of Dairy and Food Science and Technology, Egerton University. Laboratory experiment was arranged in Completely Randomized Design (CRD) with three replications where treatments were assigned to the experimental units completely at random. Randomization was done without any restrictions. Improved cowpea lines IT97K-U99-35, IT82D-889. IT82D-889-1, TEXAN PINKEYE, TX123, IT98K-205-8, IT98K-1111-1, IT97K-10U2-3, IT85F-867-5, and IT98K-589-2, and varieties KVU27-1, M66, K80, KUNDE MBOGA, and KENYA KUNDE were sourced from Kenya Agricultural Livestock Research Organisation (KALRO) Katumani Research. Cowpeas were grown at experimental stations of KALRO Katumani during the cropping seasons of 2018 short rains (SR) and 2019 long rains (LR). This location falls under semi-arid region of eastern Kenya (Ukambani) which experiences a bimodal rainfall pattern with long rains occurring from March-May and short rains from October-December [12]. Ten cowpea breeding lines, along with five improved checks/varieties were laid out in a randomized complete block design with three replications. Samples for analysis in this experiment were picked randomly. Each breeding line was planted in a 4 row plot of $4 \mathrm{~m}$ length with inter-row spacing of $0.6 \mathrm{~m}$ and intra-row spacing of $0.2 \mathrm{~m}$. Two seeds were planted per hill and later thinned to one plant per hill two weeks after emergence. The plots were maintained weed free by hand hoeing. 


\subsection{Sample Preparation}

Matured, dry grains ( $250 \mathrm{~g}$ ) were cleaned, this involves removal of foreign matter, broken seeds and immature seeds. Grains were then milled using a Microphyte lab disintegrator (miller) model Fz102 (Tianjin, China), which was fitted with $500-\mu \mathrm{m}$ sieve to give whole grain flour, and then stored at $(9 \pm 2)^{\circ} \mathrm{C}$ until all other analyses were done.

\subsection{Nutritional Analyses}

\section{Proximate composition}

Determination of moisture content

Moisture content of the samples was determined using oven-drying method according to AACC International [13], Method 44-15 A. This involved exposing samples to air oven drying at $105^{\circ} \mathrm{C}$ for $3 \mathrm{~h}$ (single stage). Moisture content was then calculated as the loss in weight expressed as a percentage of the original weight of a sample.

$$
\begin{aligned}
& \text { \%Moisture Content } \\
& =\frac{(\text { weight of pan }+ \text { wet sample })-(\text { weight of pan }+ \text { dry sample })}{\text { weight of sample }} \times 100
\end{aligned}
$$

\section{Determination of ash content}

The AOAC 942.05 method [14], was used to determine the ash content. Two (2) $\mathrm{g}$ of ground cowpea grains sample was weighed $\left(W_{1}\right)$ into a crucible that was previously calcined and weighed $\left(W_{2}\right)$, and then heated in a muffle furnace (Model: MR170; S/N: 6800616; Hereaus GMBH, Hanau, Germany) at $550^{\circ} \mathrm{C}$ for $12 \mathrm{~h}$. The crucible with the ashed sample was then cooled in a desiccator and reweighed $\left(W_{3}\right)$. Ash content was calculated using the expression:

$$
\text { Ash } \%=100 *\left(W_{2}-W_{1}\right) / W_{2}
$$

\section{Determination of crude protein content}

Determination of crude protein was done according to AOAC method 984.13 [14]. Two (2) g of cowpeas ground sample were mixed with $20 \mathrm{~mL}$ of concentrated sulphuric acid in a clean well labelled digestion tube. Kjeldahl tablets (catalyst) were added to the mixture (selenium powder and concentrated sulphuric acid $(2.8 \mathrm{~g} / 800-\mathrm{mL})$, in the tube and the sample digested in a Gerhardt Kjeldatherm digester (Model: KB40; Gerhardt GMBH and CO. Kg; Germany) for $1 \mathrm{~h}$ at $420^{\circ} \mathrm{C}$. Distilled water was added to the digest to make $80 \mathrm{~mL}$ volume. Exactly 50 $\mathrm{mL}$ of Sodium hydroxide solution was added to the mixture and followed by distillation of the ammonia into concentrated boric acid using a $2200 \mathrm{Kjeltec}^{\mathrm{TM}}$ auto distillation unit (Foss Analytical, Höganäs, Sweden). Titration was done using hydrochloric acid $(0.1 \mathrm{~mol} / \mathrm{L})$ after adding a few droplets of indicator solution. Nitrogen content $(\mathrm{g} / 100 \mathrm{~g})$ was obtained using the formula;

$$
N(\mathrm{~g} / 100 \mathrm{~g})=\left(V_{s}-V_{b}\right) \times M_{(\mathrm{HCl})} \times 1 \times 14.007 / \mathrm{W} \times 10
$$

where: $V_{s}$ is volume of $\mathrm{HCl}(\mathrm{mL})$ needed to titrate sample; $V_{b}$ is volume of $\mathrm{HCl}$ 
(mL) needed to titrate the blank test; $M_{(\mathrm{HCl})}$ is the molarity of hydrochloric acid; the numeral one (1) is the acid factor; 14.007 is the molecular weight of nitrogen; $W$ is the weight of the sample (g) and 10 is the conversion factor from $\mathrm{mg} / \mathrm{g}$ to $\mathrm{g} / 100 \mathrm{~g}$. Crude protein content was obtained by multiplying the nitrogen content by 6.25 .

\section{Determination of crude fat content}

Crude fat extraction was done according to AOAC method 920.39 [14]. Five (5) $\mathrm{g}$ of the sample was weighed $\left(W_{1}\right)$ into the extraction thimble and covered with a fat-free clean wad of cotton wool. The thimble was then fitted to a clean dry round bottom flask that had been cleaned, dried and weighed $\left(W_{2}\right)$. Exactly $25 \mathrm{~mL}$ of petroleum ether was added into the extraction flask. The Electro-thermal Soxhlet-Apparatus (Model: EME 6250/CF; Cole Parmer; England) was set to extract the sample for $6 \mathrm{~h}$, after which the solvent was evaporated, flask dried in a desiccator and reweighed $\left(W_{3}\right)$.

Crude fat content (\%) was calculated using the formula:

$$
100 *\left(W_{3}-W_{2}\right) / W_{1}
$$

$W_{1}$ is the initial sample weight in grams, $W_{2}$ is the tare weight of flask in grams, and $W_{3}$ is the weight of flask and fat residue in grams

\section{Determination of crude fibre}

Crude fiber was determined according to method 6865 [14]. Two (2) g of the grounded sample was extracted with ether to remove fat. After extraction $2 \mathrm{~g}$ of the sample was boiled with $200 \mathrm{~mL}$ of sulphuric acid for 30 Minutes, then filtered through muslin cloth and washed with boiling water until no longer acidic, then boiled with $200 \mathrm{~mL}$ Sodium hydroxide for 30 minutes, filtered through muslin cloth and washed with $25 \mathrm{~mL}$ of boiling $1.25 \%$ Sulphuric acid, $3.50 \mathrm{~mL}$ portions of water and $25 \mathrm{~mL}$ alcohol all this was done in a Fibertec digester (FOSS, Sweden). The residue was removed and transferred to ashing dish (pre-weighed dish $-W_{1}$ ). The residue was dried for $2 \mathrm{hrs}$ at $130^{\circ} \mathrm{C} \pm 2^{\circ} \mathrm{C}$ and cooled in a desiccator and weighed $\left(W_{2}\right)$. Then ignited for 30 mins @600 ${ }^{\circ} \mathrm{C}$ in muffle furnace (Model: MR170; S/N: 6800616; Hereaus GMBH, Hanau, Germany) then cooled in the desiccator and reweighed $\left(W_{3}\right)$

The formula used

Crude Fibre $=\left(W_{2}-W_{1}\right)-\left(\left(W_{3}-W_{1}\right) /\left(W_{3}-W_{1}\right)\right) /$ weight of the sample $* 100$

\section{Carbohydrate content determination:}

Carbohydrate content was calculated by difference method using the following equation.

$\%$ Carbohydrate $=100 \%-($ Moisture + Crude fat + Ash + crude protein $) \%$

\section{Minerals analyses}

Minerals determination was done using method described by AOAC [14]. Five milliliters of conc. $\mathrm{HNO}_{3}$ and $1 \mathrm{ml} \mathrm{Conc}$. $\mathrm{HClO}_{4}$ were used to digest $1 \mathrm{~g}$ of sample. Allowed to stand closed overnight at room temperature to predigest the sample and thereafter placed in oven at $100^{\circ} \mathrm{C}$ for 8 hours and cooled to room 
temperature in fume hood. Atomic absorption spectrophotometer (Thermo Jarrell Ash Corporation model 6) was used for analysis of Calcium, Magnesium, Zinc, Sodium, Phosphorus. Flame spectrophotometer (Flame photometer model 410, United Kingdom) was used for potassium and UV/visible spectrophotometer (JENWAY 7315) for phosphorus. Calcium, potassium, magnesium, sodium, zinc and phosphorus were measured at wavelengths of 422.7, 766.5, 285.2, 589.0, 213.9 and $880 \mathrm{~nm}$ respectively.

Amino Acid Profiling

Pico-Tag method, described by [15] was used to determine the amino acid composition of cowpea flour samples. The method is a three main steps procedure: hydrolysis of the protein and peptides to yield free amino acids (Performic acid was used to oxidise sulphur-containing amino acids cysteine and methionine into cysteic acid and methionine sulphone), Sodium metabisulphite was added to decompose excess performic acid, Amino acids were liberated from proteins using $6 \mathrm{~N} \mathrm{HCl}$.

Then pre-column derivatization of sample was done with O-phthalaldehyde (OPA) and analysis by reverse phase Ultra Performance Liquid Chromatography (UPLC) in fluorescence detection. The Pico-Tag column part $(3.9 \mathrm{~mm} \times 15 \mathrm{~cm})$ employed and the wavelength detector was operated at $254 \mathrm{~nm}$ hence get the peak area and read with respective calibration curves.

\section{Technological properties determination}

Grain samples was first mixed and sieved in sieves with holes of $(5.16 \times 19.05$ $\mathrm{mm}$ ) and Visibly damaged grains from insects or from mechanical processes were removed before analysis. After selection, the grains were stored in refrigerators with a stable temperature of below $10^{\circ} \mathrm{C}$.

\section{Hydration properties}

Water absorption capacity before cooking

This was determined in accordance with the modified methods described and used by [16]. Whereby $30 \mathrm{~g}$ sample of cowpea grains was placed in a $250 \mathrm{~mL}$ beaker with $100 \mathrm{~mL}$ of distilled water for $16 \mathrm{hrs}$ at ambient temperature. After the soaking period, the water was drained, the grains reweighed and the water absorption capacity before cooking (WACBC) was calculated by the formula:

$$
\mathrm{WACBC}=(s w-d w) / d w * 100
$$

in which $d w=$ beginning weight of dry grains; $s w=$ grain weight after maceration.

\section{Water absorption capacity after cooking}

The drained cowpea grains were once more placed in the beaker, with $100 \mathrm{~mL}$ of distilled water, and heated for an hour by an electric hot plate, time was monitored when the water began to boil. The broth was drained and water absorption capacity after cooking (WACAC) calculated by the formula:

$$
\text { WACAC }=(c w-d w) / d w * 100
$$

where $d w$ = beginning weight of dry grains; $c w=$ weight of grains after cooking. 


\section{Volumetric expansion and density of cowpea grains}

Determinations of the characteristics related to volumetric expansion and density of the cowpea grains was done according to method used by [16]. Ten (10) g of raw grains were weighed, which were soaked in distilled water for 16 hours at ambient temperature. After this period, the water was drained and the grains were weighed. The grains were then placed in glass jars with $100 \mathrm{~mL}$ of boiling water was added and the grains were cooked in a small cooking pan (sufuria) for 1 hour. The volume of the raw, macerated and cooked grains was determined using the water displacement principle to a graduated cylinder with a $100 \mathrm{~mL}$ capacity containing $50 \mathrm{~mL}$ of water, and the volume of displaced water was noted.

The technological characteristics of volumetric expansion of grains before cooking (VEXPBC), volumetric expansion after cooking (VEXPAC), dry grain density (R/DD), grain density after soaking (SD) and grain density after cooking $(\mathrm{CD})$ were calculated using the formulas:

$$
\begin{gathered}
\mathrm{VEXPBC}=(v s-v r) / v s * 100 \\
\operatorname{VEXPAC}=(v c-v r) / v c * 100 \\
\mathrm{R} / \mathrm{DD}=d w / v r \\
\mathrm{SD}=s w / v s \\
\mathrm{CD}=c w / v c
\end{gathered}
$$

in which

$v r=$ volume of water displaced by raw grains; $v s=$ volume of water displaced by grains after soaking; $v c=$ volume of water displaced by the grains after cooking; $d w=$ weight of the dry/raw grains; $s w=$ weight of the grains after soaking.

\subsection{Statistical Analysis}

The experiment employed a completely randomized design (CRD) in a factorial arrangement. Data obtained were subjected to analysis of variance (ANOVA) to test hypothesis using SAS (2006) version 9.1 and mean separation was done using Tukey's Honestly Significant Difference (HSD) method at 5\% level of significance.

\section{Results and Discussion}

\section{Proximate Content}

Analysis of variance was done for the completely randomized design for different lines and varieties. Variety/lines significantly affected all the proximate composition at $\mathrm{p}<0.05$.

Moisture content of cowpea grains tested in this study was statistically significantly different at $(\mathrm{p}<0.05)$. The low values of moisture ensured a long shelf life of the cowpea samples without microbial spoilage. Moisture content ranged from 12.28 to $13.35 \%$ as presented in Table 1. IT98K-205-8 had the lowest moisture content, while IT97K-U99-35 had the highest moisture content. Average 
Table 1. Proximate composition of different lines/varieties grown in eastern Kenya.

\begin{tabular}{|c|c|c|c|c|c|c|}
\hline Lines/Variety & Moisture & Ash & Fat & Protein & Crude Fibre & Carbohydrates \\
\hline IT82D-889 & $12.71^{\mathrm{ab}} \pm 0.01$ & $3.23^{\mathrm{ab}} \pm 0.05$ & $0.60^{\mathrm{ab}} \pm 0.05$ & $25.73^{\mathrm{abc}} \pm 0.88$ & $4.34^{\mathrm{a}} \pm 1.01$ & $53.40^{\mathrm{ab}} \pm 1.78$ \\
\hline IT82D-889-1 & $12.98^{\mathrm{ab}} \pm 0.07$ & $3.34^{\mathrm{ab}} \pm 0.04$ & $0.47^{\mathrm{abc}} \pm 0.14$ & $26.69^{\mathrm{abc}} \pm 1.23$ & $3.98^{\mathrm{ab}} \pm 0.29$ & $52.55^{\mathrm{ab}} \pm 1.08$ \\
\hline IT85F-867-5 & $12.97^{\mathrm{ab}} \pm 0.14$ & $3.25^{\mathrm{ab}} \pm 0.04$ & $0.47^{\mathrm{abc}} \pm 0.07$ & $25.68^{\mathrm{abc}} \pm 1.00$ & $2.90^{\mathrm{ab}} \pm 0.29$ & $54.74^{\mathrm{ab}} \pm 1.23$ \\
\hline IT97K-1042-3 & $12.99^{\mathrm{ab}} \pm 0.15$ & $3.34^{\mathrm{ab}} \pm 0.06$ & $0.21^{\mathrm{bc}} \pm 0.11$ & $28.37 c \pm 0.49$ & $3.28^{\mathrm{ab}} \pm 0.70$ & $56.45^{\mathrm{a}} \pm 0.66$ \\
\hline IT98K-205-8 & $12.28^{\mathrm{b}} \pm 0.34$ & $3.08^{\mathrm{ab}} \pm 0.11$ & $0.22^{\mathrm{bc}} \pm 0.08$ & $26.80^{\mathrm{abc}} \pm 1.00$ & $4.12^{\mathrm{a}} \pm 0.28$ & $53.52^{\mathrm{ab}} \pm 1.29$ \\
\hline IT98K-589-2 & $12.69^{\mathrm{ab}} \pm 0.19$ & $3.37^{\mathrm{a}} \pm 0.07$ & $0.48^{\mathrm{abc}} \pm 0.06$ & $24.76 \pm{ }^{\mathrm{bc}} 0.60$ & $3.58^{\mathrm{ab}} \pm 0.24$ & $55.13^{\mathrm{ab}} \pm 0.69$ \\
\hline K80 & $12.46^{\mathrm{ab}} \pm 0.13$ & $3.14^{\mathrm{ab}} \pm 0.05$ & $0.44^{\mathrm{abc}} \pm 0.13$ & $28.22^{\mathrm{ab}} \pm 1.00$ & $4.18^{\mathrm{a}} \pm 0.43$ & $51.56^{\mathrm{ab}} \pm 1.23$ \\
\hline KENYA KUNDE & $12.85^{\mathrm{ab}} \pm 0.25$ & $3.27^{\mathrm{ab}} \pm 0.06$ & $0.53^{\mathrm{abc}} \pm 0.15$ & $26.77^{\mathrm{abc}} \pm 0.54$ & $4.61^{\mathrm{a}} \pm 0.69$ & $51.98^{\mathrm{ab}} \pm 0.81$ \\
\hline KUNDE MBOGA & $12.82^{\mathrm{ab}} \pm 0.17$ & $3.31^{\mathrm{ab}} \pm 0.05$ & $0.81^{\mathrm{a}} \pm 0.10$ & $26.51^{\mathrm{abc}} \pm 0.61$ & $3.25^{\mathrm{ab}} \pm 0.72$ & $53.40^{\mathrm{ab}} \pm 1.08$ \\
\hline KVU27-1 & $12.92^{\mathrm{ab}} \pm 0.11$ & $3.27^{\mathrm{ab}} \pm 0.04$ & $0.51^{\mathrm{abc}} \pm 0.08$ & $26.10^{\mathrm{abc}} \pm 0.55$ & $1.40^{\mathrm{b}} \pm 0.18$ & $55.81^{\mathrm{ab}} \pm 0.59$ \\
\hline M66 & $13.05^{\mathrm{ab}} \pm 0.22$ & $3.22^{\mathrm{ab}} \pm 0.07$ & $0.50^{\mathrm{abc}} \pm 0.12$ & $25.74^{\mathrm{abc}} \pm 0.54$ & $3.42^{\mathrm{ab}} \pm 0.66$ & $54.07^{\mathrm{ab}} \pm 1.03$ \\
\hline TEXAN PINKIYE & $12.37^{\mathrm{ab}} \pm 0.08$ & $3.28^{\mathrm{ab}} \pm 0.05$ & $0.53^{\mathrm{abc}} \pm 0.07$ & $29.70^{\mathrm{a}} \pm 0.49$ & $3.93^{\mathrm{ab}} \pm 0.71$ & $50.09^{\mathrm{b}} \pm 0.73$ \\
\hline TX123 & $12.60^{\mathrm{ab}} \pm 0.28$ & $3.21^{\mathrm{ab}} \pm 0.05$ & $0.50^{\mathrm{abc}} \pm 0.01$ & $26.53^{\mathrm{abc}} \pm 1.66$ & $3.25^{\mathrm{ab}} \pm 0.52$ & $53.92^{\mathrm{ab}} \pm 2.36$ \\
\hline IT97K-U99-35 & $13.35^{\mathrm{a}} \pm 0.14$ & $3.34^{\mathrm{ab}} \pm 0.06$ & $0.21^{\mathrm{bc}} \pm 0.11$ & $23.37^{\mathrm{abc}} \pm 0.49$ & $3.28^{\mathrm{ab}} \pm 0.70$ & $56.45^{\mathrm{a}} \pm 0.66$ \\
\hline IT98K-1111-1 & $13.18^{\mathrm{ab}} \pm 0.12$ & $2.99^{\mathrm{b}} \pm 0.11$ & $0.13^{c} \pm 0.02$ & $25.62^{\mathrm{abc}} \pm 1.25$ & $3.00^{\mathrm{ab}} \pm 0.26$ & $55.08^{\mathrm{ab}} \pm 1.45$ \\
\hline
\end{tabular}

Key: The Values are means \pm standard deviations. Values of a parameter in a column, followed by different superscript letters which are significantly different at $\mathrm{p} \leq 0.05$ if letters are not same. Means with the same letter along the columns are not significantly different at $\mathrm{p} \leq 0.05$.

moisture content in cowpeas lines and varieties was $12.78 \%$. It was also reported that four cowpeas varieties grown in Nsukka and Enugu state of Nigerian to have moisture content ranging from $14.5 \%$ and $11.50 \%$ [17].

Total Carbohydrates were the highest components of cowpeas and not statistically and were not statistically significant at $\mathrm{p}<0.05$. Carbohydrates ranged from $50.09 \%$ to $56.08 \%$ as depicted in Table 1 . IT97K-U99-35 had the highest total carbohydrates, while TEXAN PINKIYE had the lowest. The results are same as the ones of Otitoju et al. (2015) who reported carbohydrates ranging from $49.37 \%$ to $55.74 \%$ in a study conducted on four cowpeas varieties from four different states in Nigeria.

Protein content ranged from 23.37\% (IT97-K-U99-35) to 29.70\% (TEXAN PINKIYE). These values corresponded to those obtained by other scientists, ranging from $17.4 \%$ to $31.7 \%$ [18] [19] [20] and confirmed the high nutritional value of cowpea. Cowpea protein of varieties and lines tested in this study were statistically significantly different at $(\mathrm{p}<0.05)$. It revealed that protein content of lines and varieties differ significantly. Fat content means ranged from $0.13 \%$ to $0.81 \%$ which is within the fat content range of cowpea seeds reported by [21]. This means that fat content for cowpea lines and varieties were on the lower side overall.

Crude Fibers are plant materials that remain after solvent extraction then followed by digestion with dilute alkali and acid. Crude fibers of cowpeas varieties and lines tested in this study were statistically significantly different at $(\mathrm{p}<0.05)$. 
crude fibers ranged from $1.40 \%-4.34 \%$ KVU27-1 recording the lowest and IT82D-889.

\section{Mineral Content}

Minerals are inorganic nutrients which are needed by human body in small amount. Human body needs less than 1 to $2500 \mathrm{mg}$ a day [22]. As seen in Table 2 below, almost all the varieties had no difference in the mineral contents except line IT97K-1042-3 which was lower in both calcium and magnesium. This means that the varieties absorb less of calcium and magnesium from the soils. From the results potassium indicated that it is highly concentrated across all the varieties and lines. Generally, cowpea samples may be regarded as good sources of essential minerals.

Analysis of variance was done for the completely randomized design of variety as a factor. Variety/lines significantly affected calcium and phosphorus at $\mathrm{p}<$ 0.05 while it did not significantly affect magnesium, zinc and sodium contents at $\mathrm{p}<0.05$. Sodium and potassium are normally required to maintain the body fluids osmotic balance and $\mathrm{pH}$, this regulates muscle and nerve irritability and it is able to control glucose absorption in the body. The ratio of sodium to potassium in the body is of great concern for prevention of high blood pressure (hypertension). Therefore, sodium to potassium ratio for the samples was less than one which is recommended. This means that the cowpea lines samples would not promote high blood pressure hence they are good for maintaining good health. However, results of Calcium to Phosphorus ratio in the cowpea

Table 2. Mineral contents in $\mathrm{mg} / 100 \mathrm{~g}$ of different lines/varieties flour grown in eastern Kenya.

\begin{tabular}{|c|c|c|c|c|c|c|}
\hline Line/variety & Calcium & Magnesium & Zinc & Sodium & Phosphorus & Potassium \\
\hline KVU27-1 & $2.69^{\mathrm{a}} \pm 0.63$ & $3.90^{\mathrm{ab}} \pm 0.18$ & $1.03^{\mathrm{a}} \pm 0.24$ & $218.84^{\mathrm{a}} \pm 7.48$ & $0.92^{\mathrm{a}} \pm 0.06$ & $1122.89^{\mathrm{a}} \pm 35.36$ \\
\hline TX123 & $2.07^{\mathrm{bcd}} \pm 0.37$ & $3.44^{\mathrm{b}} \pm 0.22$ & $1.23^{\mathrm{a}} \pm 0.30$ & $219.19^{\mathrm{a}} \pm 3.36$ & $1.03^{\mathrm{a}} \pm 0.06$ & $1152.62^{\mathrm{a}} \pm 28.52$ \\
\hline IT98K-205-8 & $2.25^{\mathrm{abcd}} \pm 0.42$ & $3.55^{\mathrm{ab}} \pm 0.02$ & $1.17^{\mathrm{a}} \pm 0.19$ & $220.50^{a} \pm 7.06$ & $0.85^{\mathrm{ab}} \pm 0.05$ & $1146.36^{\mathrm{a}} \pm 33.96$ \\
\hline IT98K-1111-1 & $2.07^{\mathrm{bcd}} \pm 0.43$ & $3.43^{\mathrm{b}} \pm 0.05$ & $1.18^{\mathrm{a}} \pm 0.19$ & $223.30^{a} \pm 0.65$ & $1.06^{\mathrm{a}} \pm 0.08$ & $1145.89^{\mathrm{a}} \pm 28.52$ \\
\hline IT97K-1042-3 & $1.93^{\mathrm{d}} \pm 0.44$ & $3.23^{\mathrm{b}} \pm 0.07$ & $1.21^{\mathrm{a}} \pm 0.16$ & $216.22^{\mathrm{a}} \pm 10.62$ & $0.91^{\mathrm{ab}} \pm 0.05$ & $1101.55^{\mathrm{a}} \pm 18.93$ \\
\hline IT 85F-867-5 & $2.11^{\mathrm{bcd}} \pm 0.43$ & $3.68^{\mathrm{ab}} \pm 0.24$ & $1.03^{\mathrm{a}} \pm 0.12$ & $221.45^{\mathrm{a}} \pm 6.84$ & $0.99^{\mathrm{ab}} \pm 0.07$ & $1131.58^{\mathrm{a}} \pm 11.15$ \\
\hline IT98K-589-2 & $1.97^{\mathrm{cd}} \pm 0.30$ & $3.64^{\mathrm{ab}} \pm 0.29$ & $0.89^{\mathrm{a}} \pm 0.11$ & $208.83^{\mathrm{a}} \pm 8.03$ & $0.71^{\mathrm{ab}} \pm 0.12$ & $1097.19^{\mathrm{a}} \pm 29.57$ \\
\hline M66 & $2.62^{\mathrm{ab}} \pm 0.55$ & $3.72^{\mathrm{ab}} \pm 0.20$ & $0.87^{\mathrm{a}} \pm 0.18$ & $222.31^{\mathrm{a}} \pm 0.36$ & $0.77^{\mathrm{ab}} \pm 0.04$ & $1078.94^{\mathrm{a}} \pm 21.35$ \\
\hline K80 & $2.53^{\mathrm{abc}} \pm 0.59$ & $3.70^{\mathrm{ab}} \pm 0.27$ & $0.81^{\mathrm{a}} \pm 0.04$ & $216.99^{\mathrm{a}} \pm 4.20$ & $0.89^{\mathrm{ab}} \pm 0.01$ & $1141.13^{\mathrm{a}} \pm 31.53$ \\
\hline KUNDE MBOGA & $2.20^{\mathrm{abcd}} \pm 0.38$ & $4.90^{\mathrm{a}} \pm 0.76$ & $0.80^{\mathrm{a}} \pm 0.07$ & $219.22^{\mathrm{a}} \pm 4.20$ & $0.83^{\mathrm{ab}} \pm 0.04$ & $1109.30^{\mathrm{a}} \pm 33.60$ \\
\hline KENYA KUNDE & $2.17^{\mathrm{abcd}} \pm 0.42$ & $3.71^{\mathrm{ab}} \pm 0.20$ & $0.93^{\mathrm{a}} \pm 0.08$ & $181.28^{\mathrm{a}} \pm 32.88$ & $0.62^{\mathrm{b}} \pm 0.08$ & $1071.15^{\mathrm{a}} \pm 24.08$ \\
\hline IT97-K-U99-35 & $2.27^{\mathrm{abcd}} \pm 0.39$ & $3.77 \pm 0.24$ & $0.97^{\mathrm{a}} \pm 0.20$ & $212.95^{\mathrm{a}} \pm 5.17$ & $0.83^{\mathrm{ab}} \pm 0.03$ & $1142.26^{\mathrm{a}} \pm 33.81$ \\
\hline IT82D-889 & $2.27^{\mathrm{abcd}} \pm 0.43$ & $3.74^{\mathrm{ab}} \pm 0.16$ & $0.94^{\mathrm{a}} \pm 0.10$ & $212.19^{\mathrm{a}} \pm 6.07$ & $0.87^{\mathrm{ab}} \pm 0.18$ & $1105.73^{\mathrm{a}} \pm 34.22$ \\
\hline IT82D-889-1 & $2.22^{\mathrm{abcd}} \pm 0.32$ & $3.59^{\mathrm{ab}} \pm 0.20$ & $1.22^{\mathrm{a}} \pm 0.19$ & $205.53^{\mathrm{a}} \pm 5.47$ & $0.80^{\mathrm{ab}} \pm 0.10$ & $1120.81^{\mathrm{a}} \pm 16.40$ \\
\hline TEXAN PINKIYE & $2.24^{\mathrm{abcd}} \pm 0.50$ & $3.51^{b} \pm 0.27$ & $1.01^{\mathrm{a}} \pm 0.20$ & $212.07^{\mathrm{a}} \pm 2.02$ & $0.90^{\mathrm{ab}} \pm 0.08$ & $1120.97^{\mathrm{a}} \pm 11.86$ \\
\hline
\end{tabular}

Key: The Values are means \pm standard deviations. Values of a parameter in a column, followed by different superscript letters which are significantly different at $\mathrm{p} \leq 0.05$ if letters are not same. Means with the same letter along the columns are not significantly different at $\mathrm{p} \leq 0.05$. 
samples were above two giving an indicating that this would help increase the absorption of calcium in the small intestines.

There are many factors that may account for concentrations of the elements in the cowpea seeds These factors includes concentration levels in the soil and translocation rates of the elements by the varieties or lines from the soil. Cowpea, like other crops, depends on the soil for mineral elements needed for structural and catalytic functions [23]. Presence of the major elements and the trace elements indicates that cowpea is a rich source of mineral and can be used to improve the diet people living in ASALs areas of Eastern Kenya. They are taken up by means of active transport therefore the levels in the plant tissues and seeds will be affected by the rate of active transport among other factors in plant. In this work the ten cowpea lines and five cowpea varieties differed slightly in their levels of the six mineral elements. This could be due to differences in their ability to take up mineral elements from the soil. Other possible reason is the cowpea differences that may result in their level of requirements for the mineral elements during growth.

\section{Correlation of minerals in cowpeas}

There was a significant correlation of minerals in the studied cowpea varieties and lines. From the Table 3 below an increase in calcium negatively affected the zinc and phosphorus content at $\mathrm{p}<0.001$ while an increase in the same positively led to an increase in potassium and magnesium levels at $\mathrm{p}<0.01$ and $\mathrm{p}<$ 0.001 respectively. Zinc affected positively all the minerals at $\mathrm{p}<0.001$ for sodium and potassium at $\mathrm{p}<0.001$ and phosphorus at $\mathrm{p}<0.01$.

\section{Technological Properties of Cowpea Grains}

Analysis of variance was done for the completely randomized design for variety as a factor. Variety/lines significantly affected all the technological properties at $\mathrm{p}<0.01$ except SD where it was not significant $\mathrm{p}<0.05$. According to this analysis it was found out that cowpea grains both lines and varieties were able to absorb water before cooking equivalent to their weights. This is seen with variations of (104.43\% to $114.17 \%)$ and the overall mean of water absorption before cooking was $109.3 \%$. Various studies have reported an inverse association between cooking time and water absorption [24] [25]. Therefore, cowpea lines or

Table 3. Correlation analysis between the different mineral dependent variables of different lines and varieties obtained from eastern Kenya.

\begin{tabular}{ccccccc}
\hline & Calcium & Magnesium & Zinc & Sodium & Phosphorus & Potassium \\
\hline Calcium & 1.00 & & & & & \\
Magnesium & $0.35^{* * *}$ & 1.00 & & & & \\
Zinc & $-0.56^{* * *}$ & $0.14^{\mathrm{ns}}$ & 1.00 & & & \\
Sodium & $0.08^{* * *}$ & $0.40^{* * *}$ & $0.27^{* *}$ & 1.00 & & \\
Phosphorus & $-0.39^{* * *}$ & $0.21^{*}$ & $0.41^{* *}$ & $0.29^{* *}$ & 1.00 & \\
potassium & $0.29^{* *}$ & $0.26^{*}$ & $0.64^{* * *}$ & $0.60^{* * *}$ & $0.45^{* * *}$ & 1.00 \\
\hline
\end{tabular}

Key: Significance for ${ }^{* *}=\mathrm{p}<0.001$; $^{* *}=\mathrm{p}<0.01$ and $^{*}=\mathrm{p}<0.05$. 
varieties with the highest water absorption capacity will not automatically have the shortest cooking time and vice versa [26]. Cowpea grains having differential characteristics in water absorption before cooking and after cooking which is associated with the rigidity of the seed coat, cotyledon adherence, elasticity, porosity and colloidal properties in water absorption [16]. Water absorption of legumes has been shown to be influenced by seed coat thickness and seed size [27]. Cowpea grains with high values of WACBC and WACAC are highly recommended for commercial food industries and kitchens because they yield or increase more after cooking. Generally, from results in table all the varieties and lines had good water absorption capacities. TEXAN PINKIYE cowpea line reported the highest water absorption capacity after cooking of $132.34 \%$.

For volumetric expansion it is a desirable characteristic which has an influence on acceptability of a new line, it should have high grain expansion after cooking. Volumetric expansion rate expresses water diffusion within the grains. Cowpea line IT85F-867-5 recorded the highest volumetric expansion of $64.42 \%$ therefore it is highly recommended new cowpea line, this results shows that it has low lignin level in the grain. Water diffusion is affected by lignin levels (degree of lignification) in the grain [28].

Grain densities of raw grains as high as $1.24 \mathrm{~g} \cdot \mathrm{mL}^{-1}$ dropped after soaking and further reduced after cooking as low as $1.05 \mathrm{~g} \cdot \mathrm{mL}^{-1}$. This drop in densities of the soaked and cooked grains is due to the increase in volume in relation to the weight when water is absorbed by the grain (Table 4).

Table 4. Technological properties of different lines/varieties grown in eastern Kenya.

\begin{tabular}{|c|c|c|c|c|c|c|c|}
\hline Lines/variety & WACBC & WACAC & VEXPBC & VEXPAC & R/GD & SD & $\mathrm{CD}$ \\
\hline KVU27-1 & $105.95^{\mathrm{bcd}} \pm 0.63$ & $122.97^{\mathrm{c}} \pm 0.40$ & $57.02^{\mathrm{bc}} \pm 0.34$ & $9.52^{\text {efd }} \pm 0.73$ & $1.24^{\mathrm{a}} \pm 0.01$ & $1.07^{\mathrm{a}} \pm 0.01$ & 0.01 \\
\hline TX 123 & $111.29^{\mathrm{abc}} \pm 3.03$ & $131.47^{\mathrm{b}} \pm 1.66$ & $58.65^{\mathrm{ab}} \pm 0.03$ & $59.20^{\operatorname{defg}} \pm 1.33$ & $1.17^{b c} \pm 0.02$ & $1.07^{\mathrm{a}} \pm 0.01$ & $1.05 \pm 0.02$ \\
\hline IT98K-205-8 & $104.43^{\mathrm{cd}} \pm 0.88$ & $127.79^{b c} \pm 0.43$ & $57.03^{\mathrm{bc}} \pm 0.78$ & $63.95^{\mathrm{ab}} \pm 1.27$ & $1.25^{\mathrm{a}} \pm 0.01$ & $1.18^{\mathrm{a}} \pm 0.01$ & $1.08 \pm 0.03$ \\
\hline IT98K-1111-1 & $114.17^{\mathrm{a}} \pm 1.43$ & $128.14^{\mathrm{bc}} \pm 0.55$ & $61.18^{a} \pm 0.67$ & $62.09^{\mathrm{bcd}} \pm 0.82$ & $1.22^{\mathrm{ab}} \pm 0.04$ & $1.09^{\mathrm{a}} \pm 0.01$ & $1.06^{\mathrm{de}} \pm 0.02$ \\
\hline IT97K-1042-3 & $113.45^{\mathrm{a}} \pm 1.07$ & $125.97^{\mathrm{bc}} \pm 1.72$ & $55.99^{\mathrm{bcd}} \pm 0.36$ & $63.49^{\mathrm{abc}} \pm 0.95$ & $1.25^{\mathrm{a}} \pm 0.01$ & $1.10^{\mathrm{a}} \pm 0.05$ & $1.08^{\mathrm{a}} \pm 0.02$ \\
\hline IT $85 F-867-5$ & $108.85^{\mathrm{abcd}} \pm 1.67$ & $132.01^{\mathrm{b}} \pm 0.73$ & $57.05^{b c} \pm 0.77$ & $64.42^{\mathrm{a}} \pm 0.84$ & $1.18^{\mathrm{abc}} \pm 0.01$ & $1.08^{\mathrm{a}} \pm 0.01$ & $1.05^{\mathrm{bc}} \pm 0.01$ \\
\hline IT98K-589-2 & $101.94^{\mathrm{d}} \pm 0.41$ & $107.05^{\mathrm{d}} \pm 1.20$ & $56.35^{\mathrm{bcd}} \pm 1.00$ & $57.14^{\mathrm{efg}} \pm 0.73$ & $1.18^{\mathrm{abc}} \pm 0.01$ & $1.10^{\mathrm{a}} \pm 0.01$ & $1.05^{\mathrm{e}} \pm 0.01$ \\
\hline M66 & $102.49^{\mathrm{d}} \pm 1.03$ & $122.85^{\mathrm{c}} \pm 1.53$ & $54.70^{\mathrm{cd}} \pm 0.55$ & $58.09^{\mathrm{defg}} \pm 0.77$ & $1.18^{\mathrm{abc}} \pm 0.01$ & $1.09^{\mathrm{a}} \pm 0.01$ & $1.07^{\mathrm{bc}} \pm 0.01$ \\
\hline K80 & $106.97^{\mathrm{abcd}} \pm 1.28$ & $126.88 \pm 2.01$ & $57.10^{\mathrm{bc}} \pm 0.43$ & $59.94^{\mathrm{def}} \pm 1.27$ & $1.17^{\mathrm{bc}} \pm 0.02$ & $1.07^{\mathrm{a}} \pm 0.01$ & $1.05^{\mathrm{bc}} \pm 0.01$ \\
\hline KUNDE MBOGA & $105.32^{\mathrm{bcd}} \pm 1.00$ & $125.88^{\mathrm{bc}} \pm 1.48$ & $55.94^{\mathrm{bcd}} \pm 0.69$ & $57.91^{\mathrm{efg}} \pm 1.34$ & $1.14^{\mathrm{d}} \pm 0.02$ & $1.08^{\mathrm{a}} \pm 0.01$ & $1.05^{\mathrm{bc}} \pm 0.01$ \\
\hline KENYA KUNDE & $107.39^{\mathrm{abcd}} \pm 1.13$ & $127.80^{\mathrm{bc}} \pm 1.55$ & $58.73^{\mathrm{ab}} \pm 0.52$ & $60.47^{\text {cde }} \pm 1.11$ & $1.18^{\mathrm{abc}} \pm 0.01$ & $1.08^{\mathrm{a}} \pm 0.01$ & $1.05^{\text {cde }} \pm 0.01$ \\
\hline IT97K-U99-35 & $103.81^{\mathrm{d}} \pm 0.82$ & $127.70^{\mathrm{bc}} \pm 1.12$ & $55.47^{\mathrm{bcd}} \pm 0.21$ & $60.81^{\text {bcde }} \pm 0.55$ & $1.18^{\mathrm{abc}} \pm 0.01$ & $1.13^{\mathrm{a}} \pm 0.02$ & $1.08^{\mathrm{bc}} \pm 0.01$ \\
\hline IT $82 \mathrm{D}-889$ & $107.20^{\mathrm{abcd}} \pm 0.32$ & $131.82^{\mathrm{b}} \pm 1.95$ & $53.83^{\mathrm{cd}} \pm 1.19$ & $58.17^{\mathrm{defg}} \pm 0.92$ & $1.12^{\mathrm{cd}} \pm 0.01$ & $1.12^{\mathrm{a}} \pm 0.01$ & $1.08^{\mathrm{bc}} \pm 0.01$ \\
\hline IT82D-889-1 & $107.46^{\mathrm{abcd}} \pm 0.92$ & $144.42^{\mathrm{a}} \pm 2.06$ & $52.94^{\mathrm{d}} \pm 0.31$ & $58.20^{\operatorname{defg}} \pm 0.05$ & $1.12^{\mathrm{cd}} \pm 0.01$ & $1.11^{\mathrm{a}} \pm 0.01$ & $1.08^{b c d} \pm 0.02$ \\
\hline TEXAN PINKIYE & $112.10^{\mathrm{ab}} \pm 0.31$ & $132.34^{\mathrm{b}} \pm 0.95$ & $53.33^{\mathrm{cd}} \pm 0.81$ & $55.20^{\mathrm{g}} \pm 0.62$ & $1.14^{\mathrm{d}} \pm 0.01$ & $1.09^{\mathrm{a}} \pm 0.01$ & $1.06^{\mathrm{cde}} \pm 0.01$ \\
\hline
\end{tabular}

Key: The Values are means \pm standard deviations. Values of a parameter in a column, followed by different superscript letters which are significantly different at $\mathrm{p} \leq 0.05$ (letters are not same). Means with the same letter along the columns are not significantly different at $\mathrm{p} \leq 0.05$. Values of water absorption capacity before cooking (WACBC) and after cooking (WACAC), volumetric expansion before. cooking (VEXPBC) and after cooking (VEXPAC), dry/raw grain density (R/DD), grain density after soaking (SD) and grain density after cooking (CD) of the grains of varieties/lines of cowpeas from KALRO Katumani Kenya. 


\section{Amino acids content of cowpea lines}

Nutrient value or protein quality of certain food normally depends on its amino acid content, the physiological utilization of specific amino acid after digestion, absorption and final utilization. Cowpea lines and varieties (check) are rich in isoleucine, leucine, lysine and tyrosine and phenylalanine (aromatic amino acids) (Table 5). The most abundant amino acids are glutamic and aspartic acids. Total essential amino acids were high compared to non-essential amino acids. Cowpea samples seeds are low in sulphur amino acids, methionine and cysteine but are moderately high in lysine contents. These cowpea lines are good sources of most of the essential amino acids. Therefore, highly suitable and hence recommended for the fortification of cereal products mostly used as weaning foods for children in most Kenyan communities, especially in Eastern Kenya.

IT97K-1042-3 line had higher amounts of amino acids on average as compared to other cowpea lines. Methionine was higher in IT97K-1042-3 (0.38 $\mathrm{mg} / 100 \mathrm{~g})$, and TEXAN PINKIYE $(0.37 \mathrm{mg} / 100 \mathrm{~g})$. The two lines recorded high histidine level of $0.84 \mathrm{mg} / 100 \mathrm{~g}$ compared to others. Difference in profiles of amino acids is probably derived from genetic and agronomic factors that may influence the amino acid profile [29] (Pandurangan et al., 2015). Low content of

Table 5. Amino acids contents of different lines grown (g/100 g sample) of cowpea flour.

\begin{tabular}{|c|c|c|c|c|c|c|c|c|c|c|}
\hline & $\begin{array}{l}\text { IT97K- } \\
\text { U99-35 }\end{array}$ & $\begin{array}{c}\text { IT82D- } \\
889\end{array}$ & $\begin{array}{l}\text { IT82D- } \\
889-1\end{array}$ & $\begin{array}{c}\text { TEXAN } \\
\text { PINKIYE }\end{array}$ & TX 123 & $\begin{array}{c}\text { IT98K- } \\
205-8\end{array}$ & $\begin{array}{l}\text { IT98K- } \\
1111-1\end{array}$ & $\begin{array}{l}\text { IT97K- } \\
1042-3\end{array}$ & $\begin{array}{c}\text { IT85F- } \\
867-5\end{array}$ & IT98K-589-2 \\
\hline Methionine & 0.33 & 0.33 & 0.33 & 0.37 & 0.34 & 0.34 & 0.34 & 0.38 & 0.35 & 0.33 \\
\hline Cysteine & 0.25 & 0.24 & 0.23 & 0.26 & 0.23 & 0.23 & 0.23 & 0.28 & 0.23 & 0.22 \\
\hline $\begin{array}{c}\text { Methionine + } \\
\text { Cysteine }\end{array}$ & 0.58 & 0.57 & 0.55 & 0.63 & 0.57 & 0.57 & 0.58 & 0.66 & 0.58 & 0.55 \\
\hline Lysine & 1.56 & 1.55 & 1.56 & 1.74 & 1.59 & 1.65 & 1.61 & 1.82 & 1.60 & 1.49 \\
\hline Threonine & 0.84 & 0.83 & 0.87 & 0.97 & 0.90 & 0.90 & 0.91 & 1.01 & 0.89 & 0.86 \\
\hline Arginine & 1.71 & 1.71 & 1.67 & 1.99 & 1.87 & 1.82 & 1.87 & 2.14 & 1.80 & 1.53 \\
\hline Ileum & 0.96 & 0.97 & 1.00 & 1.09 & 1.03 & 1.05 & 1.03 & 1.13 & 1.02 & 0.95 \\
\hline Valine & 1.16 & 1.15 & 1.18 & 1.29 & 1.21 & 1.23 & 1.22 & 1.32 & 1.19 & 1.12 \\
\hline Histidine & 0.76 & 0.73 & 0.71 & 0.84 & 0.80 & 0.80 & 0.83 & 0.84 & 0.75 & 0.69 \\
\hline Phenylalanine & 1.32 & 1.31 & 1.33 & 1.43 & 1.35 & 1.42 & 1.36 & 1.49 & 1.32 & 1.25 \\
\hline Glycine & 0.86 & 0.94 & 0.96 & 0.99 & 0.89 & 0.92 & 0.90 & 1.06 & 0.98 & 0.89 \\
\hline Serine & 1.12 & 1.10 & 1.14 & 1.27 & 1.17 & 1.22 & 1.19 & 1.35 & 1.17 & 1.11 \\
\hline Proline & 0.94 & 0.96 & 0.94 & 1.01 & 0.96 & 1.02 & 0.98 & 1.09 & 0.95 & 0.90 \\
\hline Alanine & 0.94 & 0.94 & 0.97 & 1.08 & 0.98 & 1.01 & 0.99 & 1.11 & 0.99 & 0.94 \\
\hline Asphartic & 2.73 & 2.60 & 2.64 & 3.04 & 2.93 & 2.98 & 3.10 & 3.0 & 2.83 & 2.54 \\
\hline
\end{tabular}


methionine and cysteine and high content of lysine observed in this cowpea lines in this study can be complemented by inclusion with cereal food preparations. This is because cereals have lysine as a limiting amino acid and an excess of methionine, hence this combination would provide a complete protein for all essential amino acids [30] (Cervantes et al., 2014).

\section{Conclusion and Recommendations}

Cowpeas moisture content, total carbohydrates, crude ash, crude fat, crude protein, amino acids technological properties and minerals (calcium, magnesium, sodium, zinc, potassium, and phosphorus) were analyzed. The moisture content, crude fibre and crude fat across all the samples in this study were low, while total carbohydrates were high. There was no significant difference in moisture content, carbohydrates and protein content between varieties and lines. Cowpea line IT97K-1042-3 and TEXAN PINKIYE recorded the highest amount of crude protein. Regarding minerals, there was no significant difference in calcium, magnesium, zinc and potassium except line IT97K-1042-3 which was lower in both calcium and magnesium. There were higher amounts of potassium in all the varieties and lines. Considering nutritional content of both varieties and lines, they are good source of nutrients and they can be used for processing of different foods especially as an ingredient in enriching other foods like baby foods and for preparation of different dishes.

This study has shown that cowpea line TEXAN PINKIYE, IT85F-867-5, IT82D-889-1, IT98K-205-8, IT97K-1042-3 and IT82D-889 have desirable attributes such as high crude protein contents, good water absorption capacities and high volumetric expansion. IT97K-1042-3 having good amino acid patterns compared to the rest. They compared well with existing varieties like K80 and KVU27-1 though more superior than them. These cowpea lines could possibly be combined into a single cowpea line and further improved by breeders to have other good properties such as high proteins percentages, higher levels of water absorption during soaking hence reduced cooking times. However, further studies on the presence of oligosaccharides and other antinutrients that affect the utilization of cowpeas, as well as sensory evaluation studies on those breeding lines that look very promising from a nutritional standpoint, are necessary at this stage.

\section{Acknowledgements}

The authors would like to acknowledge the financial support received from RUFORUM TAGDEv Egerton University Njoro, Kenya in conducting this study. We also wish to thank Egerton University for providing laboratory facilities, Kenya Agricultural Livestock and Research Organisation (KALRO) under National Research Fund (NRF) for providing cowpeas research samples for analysis and partly funding analysis.

\section{Conflicts of Interest}

The authors declare no conflicts of interest regarding the publication of this paper. 


\section{References}

[1] Salami, A., Kamara, A.B. and Brixiova, Z. (2010) Smallholder Agriculture in East Africa: Trends, Constraints and Opportunities. African Development Bank, Tunis.

[2] Zorya, S., Morgan, N., Diaz Rios, L., Hodges, R., Bennett, B., Stathers, T. and Lamb, J. (2011) Missing Food: The Case of Postharvest Grain Losses in Sub-Saharan Africa. World Bank, Washington DC, 116.

[3] Tadele, Z. (2018) African Orphan Crops under Abiotic Stresses: Challenges and Opportunities. Scientifica, 2018, Article ID: 1451894. https://doi.org/10.1155/2018/1451894

[4] Mutungi, C. and Affognon, H. (2013) Addressing Food Losses: Status and Way Forward for Postharvest Research and Innovations in Kenya. ICIPE Policy Brief; No. 5/13.

[5] Mbaya, D., Bitok, L.K., Karani, A.K., Osano, B. and Habtu, M. (2015) Outcomes of Severely Malnourished Children Aged 6-59 Months on Outpatient Management Program in Kitui County Hospital, Kenya. Open Journal of Pediatrics, 5, 326. https://doi.org/10.4236/ojped.2015.54049

[6] NDMA, Kitui County Kenya (2017) Drought Monitoring and Early Warning Bulletin. NDMA.

[7] Awika, J.M. and Duodu, K.G. (2017) Bioactive Polyphenols and Peptides in Cowpea (Vigna unguiculata) and Their Health Promoting Properties: A Review. Journal of Functional Foods, 38, 686-697. https://doi.org/10.1016/j.jff.2016.12.002

[8] Timko, M.P. and Singh, B.B. (2008) Cowpea, a Multifunctional Legume. In: Genomics of Tropical Crop Plants, Springer, New York, 227-258.

https://doi.org/10.1007/978-0-387-71219-2_10

[9] Langyintuo, A.S., Lowenberg-DeBoer, J., Faye, M., Lambert, D., Ibro, G., Moussa, B. and Ntoukam, G. (2003) Cowpea Supply and Demand in West and Central Africa. Field Crops Research, 82, 215-231. https://doi.org/10.1016/S0378-4290(03)00039-X

[10] Gonçalves, A., Goufo, P., Barros, A., Domínguez-Perles, R., Trindade, H., Rosa, E.A. and Rodrigues, M. (2016) Cowpea (Vigna unguiculata L. Walp), a Renewed Multipurpose Crop for a More Sustainable Agricultural-Food System: Nutritional Advantages and Constraints. Journal of the Science of Food and Agriculture, 96, 2941-2951. https://doi.org/10.1002/jsfa.7644

[11] Singh, S.R. and Jackai, L.E.N. (1985) Insect Pests of Cowpeas in Africa: Their Life Cycle, Economic Importance and Potential for Control. Cowpea Research, Production and Utilization, 2, 217-231.

[12] Jaetzold, R., Schmidt, H., Hornetz, B. and Shisanya, C. (2006) Farm Management Handbook of Kenya Vol. II: Natural Conditions and Farm Management Information 2nd Edition Part C, East Kenya, Subpart C1 Eastern Province. Ministry of Agriculture, Nairobi, 573.

[13] AOAC (Association of Official Analytical Chemists) International (2007) Official Methods of Analysis. 18th Edition, AOAC International, Gaithersburg.

[14] AACC International (2000) Approved Methods of the American Association of Cereal chemists. 11th Edition, Method 46-10.01, The Association, St. Paul.

[15] Perina, E.F., Carvalho, C.R.L., Chiorato, A.F., Lopes, R.L.T., Gonçalves, J.G.R. and Carbonell, S.A.M. (2014) Technological Quality of Common Bean Grains Obtained in Different Growing Seasons. Journal of Bragantia, 73, 14-22. https://doi.org/10.1590/brag.2014.008

[16] Otitoju, G.T.O., Otitoju, O., Nwamarah, J.U. and Baiyeri, S.O. (2015) Comparative 
Study of the Nutrient Composition of Four Varieties of Cowpea (Vigna unguiculata) and Their Products (Beans-Based Products). Pakistan Journal of Nutrition, 14, 540. https://doi.org/10.3923/pjn.2015.540.546

[17] Frota, K.M.G., Soares, R.A.M. and Areas, J.A.G. (2008) Chemical Composition of Cowpea (Vigna unguiculata L. Walp), BRS-Mileniocultivar. Science and Food Technology, 28, 470-476.

[18] Onwuliri, V.A. and Obu, J.A. (2002) Lipids and Other Constituents of Vigna unguiculata and Phaseolus vulgaris Grown in Northern Nigeria. Food Chemistry, 78, 1-7. https://doi.org/10.1016/S0308-8146(00)00293-4

[19] Thangadurai, D. (2005) Chemical Composition and Nutritional Potential of Vigna unguiculata ssp. Cylindrica (Fabaceae). Journal of Food Biochemistry, 29, 88-98. https://doi.org/10.1111/j.1745-4514.2005.00014.x

[20] Carvalho, A.F.U., de Sousa, N.M., Farias, D.F., da Rocha-Bezerra, L.C.B., da Silva, R.M.P., Viana, M.P., Gouveia, S.T., Sampaio, S.S., de Sousa, M.B., de Lima, G.P.G., de Morais, S.M., Barros, C.C. and Filho, F.R.F. (2012) Nutritional Ranking of 30 Brazilian Genotypes of Cowpeas Including Determination of Antioxidant Capacity and Vitamins. Journal of Food Composition and Analysis, 26, 81-88. https://doi.org/10.1016/j.jfca.2012.01.005

[21] Chavan, J.K., Kadam, S.S. and Salunkhe, D.K. (1989) Cowpea. In: Salunkhe, D.K. and Kadam, S.S., Eds., Handbook of World Food Legumes. Nutritional Chemistry, Process Technology and Utilization, Vol. 2, CRC Press, Boca Raton.

[22] Soetan, K.O., Olaiya, C.O. and Oyewole, O.E. (2010) The Importance of Mineral Elements for Humans, Domestic Animals and Plants. African. Journal of Food Science, 4, 200-222.

[23] Purves, W.K., Orians, H.G. and Heller, C.H. (1992) Life. Brain Research Bulletin, 5, 679-682.

[24] Dalla Corte, A., Moda-Cirino, V., Scholz, M.B.S. and Destro, D. (2003) Environment Effect on Grain Quality in Early Common Bean Cultivars and Lines. Crop Breeding and Applied Biotechnology, 3, 193-202. https://doi.org/10.12702/1984-7033.v03n03a03

[25] Rodrigues, A.J., Ribeiro, D.N., Poerchi, L.N., Londero, G.M.P. and Cargnelutti Filho, A. (2004) Standardization of Imbibition Time of Common Bean Grains to Evaluate Cooking Quality. Crop Breeding and Applied Biotechnology, 4, 465-471. https://doi.org/10.12702/1984-7033.v04n04a14

[26] Carbonell, S.A.M., Carvalho, C.R.L. and Pereira, V.R. (2003) Technological Quality of Beans from Common Bean Genotypes Grown in Different Environments. Bragantia, 62, 369-379. https://doi.org/10.1590/S0006-87052003000300004

[27] Giami, S.Y. (2001) Quality Attributes of Three New Improved Lines of Nigerian Lima Beans (Phaseolus lunatus L. Walp.). Plant Foods for Human Nutrition, 56, 325-333. https://doi.org/10.1023/A:1011820907356

[28] Teixeira, I.R., Borém, A., Araújo, G.A.A. and Andrade, M.J.B. (2005) Nutrient Content and Physiological Quality of Bean Seeds in Response to Foliar Fertilization with Zinc and Manganese. Journal of Bragantia, 64, 83-88. https://doi.org/10.1590/S0006-87052005000100009

[29] Pandurangan, S. (2015) Differential Response to Sulfur Nutrition of Two Common Bean Genotypes Differing in Storage Protein Composition. Frontiers in Plant Science, 6, 92. https://doi.org/10.3389/fpls.2015.00092

[30] Cervantes-Pahm, S.K., Liu, Y. and Stein, H.H. (2014) Digestible Indispensable Amino Acid Score and Digestible Amino Acids in Eight Cereal Grains. British Journal of Nutrition, 111, 1663-1672. https://doi.org/10.1017/S0007114513004273 